\title{
Information literacy and open access in Croatian academic libraries
}

\author{
Ivana Hebrang Grgic
Department of Information and Communication Sciences,
culty of Humanities and Social Sciences, University of Zagreb, \\ Ivana Hebrang Grgic
Department of Information and Communication Sciences,
culty of Humanities and Social Sciences, University of Zagreb, \\ Ivana Hebrang Grgic
Department of Information and Communication Sciences,
Faculty of Humanities and Social Sciences, University of Zagreb, \\ Zagreb, Croatia
}

\begin{abstract}
Purpose - The purpose of this paper is to present results of a survey of Croatian academic libraries' user education about open access (OA)-related issues. The concept of OA literacy will be explained, and the term will be put in the context of information literacy (IL) and scholarly communication.

Design/methodology/approach - An anonymous online questionnaire was sent to all the Croatian academic libraries with the aim to find out if libraries are involved in OA and to learn about plans for user education about the aspect of $\mathrm{IL}$ that is important for using OA information.

Findings - Almost all the libraries are involved in OA publishing, either through OA repositories or through OA journals. However, 22 per cent of the libraries do not educate their users about OA. Two most important IL skills in the context of OA are finding OA information and understanding OA citation advantage. Academic libraries in Croatia mostly recognize the questionable publishers as a threat for OA. However, 40 per cent of libraries do not plan any form of education about OA literacy. Practical implications - The results of this research can be a basis for creating programmes of user education in academic libraries. Some problems are recognized, some skills are identified and further steps could be undertaken to improve academic library users' OA literacy skills.

Originality/value - The research results contribute to understanding the importance of academic libraries in developing OA literacy of their users. The paper gives results of a survey of Croatian academic libraries and some new perspectives for authors, readers and libraries on how to evaluate OA sources using OA literacy skills.
\end{abstract}

Keywords Academic libraries, Croatia, Library users, Information literacy, Open access,

Open access literacy

Paper type Research paper

\section{Introduction}

Two movements are extremely important for scholarly communication in the twenty-first century. The older one is information literacy (IL) movement that evolved from library user education (sometimes also called bibliographic instructions). Currently, its scope is expanded, it entered classrooms and is an important part of lifelong learning. Scholarly communication is impossible without implementation of IL skills - scholars from all disciplines have to know how to search for information, how to evaluate it, how to produce and present new information in a proper, ethical manner. They have to know how to make their information more visible and accessible, how to improve its quality and impact. Another movement that can help scholars in their efforts to publish scholarly information is open access (OA). Its idea is to make scholarly

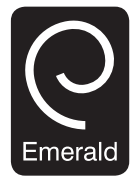


LR

$65,4 / 5$

256

information accessible to the widest possible public, without barriers and restrictions, so it could be used to improve scholarly communication to advance science and to ensure progress of mankind. Because of diversity of all kinds of information that can be accessed for free on the internet, it is important to develop and accept IL skills to ensure that scholarly information in $\mathrm{OA}$ is valid, reliable, properly published and used. Academic libraries should have an important role in developing those skills among their users (students and scholars).

\section{Literature review - information literacy and open access}

Libraries are, traditionally, places that collect and archive information, making them available to their users. Users have to learn, with the help of librarians, how to find, evaluate and use information. As characteristics of information resources change, IL skills become more and more important. IL was defined by Zurkowski (1974) and since then it has become an important part of social, economic, technological and scientific discourses. Some approaches describe IL as a set of skills and competencies, e.g. American Library Association (ALA, 1989); some of them define it as a social phenomenon, e.g. Alexandria Proclamation (2005) and some of them (Špiranec and Banek Zorica, 2008) suggest that the complete definition lies in combining the two models. With the development of information and communications technology, many new subcategories of IL emerged (so called 21st century literacies). When defining IL, Bawden (2001) describes three skill based literacies - digital literacy, media literacy and library literacy. Ferguson (2005) writes about basic literacy, library literacy, media literacy, technology literacy and visual literacy. Špiranec and Banek Zorica (2012) introduced the term IL 2.0 as a subset of IL that evolves from Web 2.0.

Analysing IL in the context of scholarly communication, there are several important subcategories of IL. Arnett et al. (2009) provide a framework for communication ethics literacy introducing ethics as an important skill for proper and valid communication. Gilliver-Brown and Johnson (2009) write about academic literacy, mentioning multiliteracies that are required for students as future researchers. The Organisation for Economic Co-operation and Development's (OECD) programme for international student assessment defines scientific literacy as:

[...] the capacity to use scientific knowledge, to identify questions and to draw evidence-based conclusions in order to understand and help make decisions about the natural world and human interactions with it (OECD, 2003).

Jones-Kavalier and Flannigan (2006) describe digital literacy as "the ability to read and interpret media [...], to reproduce data and images through digital manipulation, and to evaluate and apply new knowledge gained from digital environments". Additionally, Gurak (2001) defines cyber literacy as specific literacy that incorporates new aspects of the internet that include active participation and communication.

There are also several terms that combine literacies - transliteracy and metaliteracy. Ipri (2010) defines transliteracy as an area where scholarly communication and IL interact. Transliteracy is concerned with the social meaning of literacy:

[...] exploring the participatory nature of new means of communicating which breaks down barriers between academia and the wider community and calls into question standard notions of what constitutes authority by emphasizing the benefits of knowledge sharing via social networks. 
Mackey and Jacobson (2011) reframe IL as a metaliteracy, claiming that "metaliteracy provides an integrated and all-inclusive core for engaging with individuals and ideas in digital information environments".

Association of college and research libraries (ACRL, 2013) explores intersections between IL and scholarly communication. The three intersections are economics of scholarship, digital literacies and the new role of libraries. Recommendations are given for libraries, faculties and organizations:

- integration of pedagogy and scholarly communication in librarians' education;

- developing new model of IL curricula; new organizational models should be explored and training should be available to librarians; and

- all levels in organizations should be included in discussions about IL and scholarly communication and the value of libraries should be articulated.

Ogburn (2013) explains the importance of academic libraries in connecting IL and scholarly communication. For example, scholars are not always aware of the importance of decisions on where to publish their work. Sometimes they want to use new models and approaches not knowing how to get started. The role of library is to explore new publishing models and to advise their users. Gelfand and Palmer (2013) identify theoretical framework that academic libraries should use to plan education activities for their users. They analyse number of documents to conclude how important academic libraries are for aligning IL and scholarly communication. Duckett and Warren (2013) give a wide socio-cultural and economical frame for IL in the context of scholarly communication explaining the dichotomy of the two concepts and the role of librarians in finding intersections between the concepts.

Hall (2015) writes about IL gap in scholarly communication - the gap is based on scholars' conservative attitudes towards scholarly communication. The important role of library is to be a leader in promotion of new models such as OA, by organizing seminars, workshops or similar activities.

As OA model changes the paradigm of scholarly communication, some IL skills are important for the model in a way that would advance dissemination of research results.

OA was a reaction to so-called access crisis (high subscription prices of scholarly journals which many libraries could not afford to purchase, especially libraries in less developed countries). Basically, $\mathrm{OA}$ is free and unrestricted online availability of scientific journal literature (BOAI, 2002). The idea and the concept were hoped to be deus ex machina at the time when access crisis culminated because electronic publishing was thought to be easier, faster and cheaper than print publishing. There are two ways of achieving $\mathrm{OA}-\mathrm{OA}$ journals and OA repositories.

First experiments with publishing free journals on the internet began at the end of 1980s. The first freely available electronic scholarly journal, Psycholoquy, was launched in 1989 (peer-reviewed since 1990) and was followed by The Public-Access Computer Systems Review (in 1989), Electronic Journal of Communication (in 1990) and others (Suber, 2009). OA advocates tried to prove that electronic publishing is much cheaper than print publishing. Some new journals evolved from the old, subscription-based journals and were based on the editors' discontent with restricted access policies. Those new journals were launched after their editorial boards had resigned from the old journals, declaring so-called "journal declarations of independence" (OAD, 2014). 
LR

$65,4 / 5$

258

Harnad (1994) initiated an internet discussion explaining his own vision of electronic publishing. He proposed that authors should publish their papers for free on the internet because, traditionally:

[...] scholarly author wants only to publish them, that is, to reach the eyes and minds of peers [...], so that they can build on one another's contributions in that cumulative collaborative enterprise called learned inquiry.

Many authors have compared costs of print and electronic scholarly journals, concluding that there are cost savings in electronic publishing, e. g. Odlyzko (1995); Bot et al. (1998) and Jacsó (2006).

Besides OA journals, another way to achieve OA is through free electronic archives OA repositories. The first electronic archive was ArXive, launched in Los Alamos in 1991. OA repositories can be institutional, national, disciplinary, governmental, etc; they should use open-source software; they can archive various material types and they should be Open Access Initiative Protocol for Metadata Harvesting (OAI-PMH) compliant to ensure interoperability. As recommended in BOAI, 10 (2012), deposits of journal articles in OA repositories should be made at the time of acceptance, no later than the formal publication date. That is a recommendation, but authors and librarians have to be aware of different publishers' policies - SHERPA/RoMEO (2016) database is a source of information on the policies.

Although debatable, many authors believe that OA citation advantage is proved e.g. A. Swan (2010) finds 27 articles that prove OA citation advantage, comparing to 4 articles that do not prove the advantage. The proportion is 39:7 in Wagner's bibliography (Wagner, 2010). OA journal publishing has rapidly increased since 2000 number of OA journals in 2000 was 740, in 2009 it was 4,769 (Laakso et al., 2011), and, at the end of 2015, there were more than 10,000 OA journals in the directory of open access journals (DOAJ, 2015). It is obvious that electronic journals are the future of journal publishing. OA model will probably not become the only model but will coexist with traditional (and eventually some new) publishing models.

Lately, there are some considerations if the original goals of OA are achieved (Rizor and Holley, 2014), and it is obvious that there will be more discussions about the current state of OA and its consequences. Although the idea of OA seemed to be the ideal solution, numerous problems have appeared during its implementation, e.g. copyright issues, interoperability problems, funding models and the threat of so-called predatory publishers (or questionable publishers). That is where OA and IL meet - IL skills are important for using and producing OA information, and libraries are the places where scholars (and students) should be taught how to find, evaluate and use OA sources. The term OA literacy could be used for the set of skills.

\section{User education about open access in Croatian academic libraries Research questions and hypothesis}

Academic libraries should play an important role in educating their users about OA. The users are scientists, educators and students who use and/or produce OA information. A survey was conducted to find out if (and how) user education about $\mathrm{OA}$ is organized and planned in Croatian academic libraries.

The aim of the survey was to test the needs for education about $\mathrm{OA}$ by investigating experiences and attitudes of Croatian academic librarians because they are acquainted 
with information needs of their users and they know about their involvement and their interest in $\mathrm{OA}$.

Five main research questions were identified:

$R Q 1$. How does number of librarians, number of users and/or scientific field effect education programmes?

RQ2. How many libraries and their institutions are involved in OA publishing (either by maintaining institutional OA repository or by taking part in editing OA journal, or both)?

RQ3. Do librarians think there is a need for education about OA among their users?

$R Q 4$. Which methods do libraries use to educate their users about OA?

RQ5. Which are librarians' plans for education about OA in the next two-year period?

RQ6. Which topics and skills about OA do librarians consider the most interesting for their users?

Hypothesis was that the majority of libraries organize at least some kind of education (e.g. through library's website) but have problems with lack of space, staff and/or technology. Library users have heard about OA but do not know enough to use it in a proper way. It was also presumed that the most interesting topic would be finding and evaluating information in OA (for all users) and OA citation advantage (for scientists).

The survey results were supposed to give a platform for developing education programmes about OA literacy, the part of IL that involves competencies for evaluating and using OA sources.

\section{Methods and sample}

An online questionnaire was distributed to 86 Croatian academic libraries whose e-mails were extracted from two databases - database of Croatian academic libraries maintained by the National and University Library in Zagreb and Register of Croatian libraries maintained by the Croatian Ministry of Culture. The questionnaire was sent in May 2015, and response rate was 57 per cent (i.e. 49 libraries).

The questionnaire had ten questions. The first four were general questions about library type (faculty, university or institute library), scientific field, number of librarians and number of users. The next group of questions was about using OA in the institutions (Does your institution have an OA repository? Does your institution publish an OA journal?) and about current methods of user education (Which education methods do you use when educating users about OA?). The last group of questions was focused on the future of OA education in libraries. Respondents had to choose a degree of users' interest in $15 \mathrm{OA}$ topics (the topics are listed in Table III). Librarians also had to answer if they plan education about OA, and, if not, why (e.g. insufficient number of librarians, uninterested users, etc.).

\section{Data presentation}

Out of 49 libraries that responded to the questionnaire, 36 (73.5 per cent) are libraries at higher education institutions (universities or faculties) and 13 (26.5 per cent) are libraries at scientific institutes. The field of science, technology and medicine is covered by 
LR

$65,4 / 5$

\section{0}

Table I.

Number of institutional library users in Croatian academic libraries
29 libraries (49.2 per cent) and the field of social sciences and humanities by 22 libraries (44.9 per cent). Two libraries partly cover both fields.

Libraries have in average 4.2 employed librarians, and average number of users is 1,700 (Table I). Some library services are available online and can be used by the whole academic community in Croatia and worldwide (e.g. OA repositories).

Libraries at Croatian academic institutions are involved in achieving OA - 40 institutions publish at least one $\mathrm{OA}$ journal, and nine have institutional repositories that archive at least some material in OA. There are 11 libraries in the sample (22.4 per cent) that do not educate their users about OA. The other 38 libraries mostly use individual approach (30 libraries) but also several other ways of education - publishing information on websites, organizing seminars or workshops, publishing handbooks, publishing posts on social networking sites, organizing lectures for students in classrooms, organizing webinars and conferences (Table II).

According to librarians' opinion, users of eight libraries (16.3 per cent) know enough about OA, users of 29 libraries (59.2 per cent) know something but not enough and users of 12 libraries (24.5 per cent) are not familiar with OA at all.

The majority of the 15 skills that were proposed in the questionnaire, were evaluated by respondents as interesting or very interesting for users. The ranking was from 1 (not interesting at all) to 5 (extremely interesting). The most interesting skill for library users is finding $\mathrm{OA}$ information on the internet. Understanding OA citation advantage is the second most important skill (it is more interesting for institute libraries than for faculty and university libraries), followed by evaluation of OA journals, copyright issues, evaluation of OA repositories, open data, etc. (Table III).

Asked about future plans for education, 19 libraries (38.8 per cent) answer that they have problems with organizing education about OA and, therefore, do not plan the education in the next two-year period. Nevertheless, they think IL in the context of OA

No. of users from the institution

No. of libraries

Less than 500

$500-1,000$

$1,000-2,000$

$2,000-5,000$

$5,000-10,000$

More than 10,000
15

10

9

7

2

1
Education methods

Percentage of libraries (\%)

Individual education

Information on library's website

Seminars or workshops organized by library

Publishing handbooks on OA

Table II.

Education methods in Croatian academic libraries on $\mathrm{OA}$
Posts on social networking sites

Lectures for students

Webinars organized by library

Conferences organized by library
61.2

34.7

30.6

18.4

12.2

6.1

4.1

4.1 


\begin{tabular}{|c|c|c|}
\hline OA literacy skill & Average & croatian \\
\hline Finding $\mathrm{OA}$ information & 4.30 & libraries \\
\hline Understanding OA citation advantage & 4.21 & \\
\hline Evaluating OA journals & 4.13 & \\
\hline Copyright and licencing & 4.00 & \\
\hline Strategies to achieve OA & 3.98 & 26 \\
\hline Evaluating OA repositories & 3.90 & 20 \\
\hline Open data & 3.76 & \\
\hline Identification questionable publishers & 3.72 & \\
\hline Unique identification of authors in OA papers & 3.66 & \\
\hline Identification of different versions of papers in $\mathrm{OA}$ & 3.56 & Table III. \\
\hline Self-archiving & 3.44 & Ranking of the $\mathrm{OA}$ \\
\hline New formats in electronic environment & 3.26 & literacy skills, as \\
\hline Definitions of OA & 3.25 & estimated by \\
\hline Altmetrics & 3.13 & librarians of Croatian \\
\hline Interoperability of repositories & 2.95 & academic libraries \\
\hline
\end{tabular}

is very interesting and very important topic for their users. Problems that those libraries are facing are insufficient number of librarians (13 libraries, all of them with one or two librarians), lack of users' interest (6 libraries), insufficient technical support (4 libraries) and lack of space in the library (3 libraries).

\section{Data analysis}

When analysing Croatian academic libraries, a very important issue is the number of librarians: 43 (or 87.8 per cent) libraries have no more than five employed librarians (13 libraries only one and 18 libraries two librarians). Only six libraries have more than five librarians (the biggest library has 52 librarians). Librarians who work alone in their libraries do not have enough time for planning and conducting user education, although they are aware of its importance and necessity. Libraries with more librarians plan more OA education. For planning education, the number of users is also relevant, as well as users' profile (students and/or scientists) and scientific discipline of a specific library (answer to $R Q 1$ ).

Answer to $R Q 2$ (how many libraries are involved in $\mathrm{OA}$ ) shows that Croatian academic libraries take an important part in achieving OA of their institutions' research results (9 of them by launching OA repositories and 40 of them by helping in publishing OA journals). Libraries usually initiate the launch of OA repositories and librarians are important as members of working groups and decision making teams (e.g. librarians should participate in decisions about repository software, material types, language, OA policy, etc.). When analysing the number of OA repositories, it is interesting to mention that, according to 2010 survey (Hebrang Grgic and Barbaric, 2011), there were only five $\mathrm{OA}$ institutional repositories in Croatia (only three with full-texts of all the deposited items). This new survey indicates that the number is higher in 2015, and the launch of new national platform Dabar in August 2015 will increase number of OA IRs. Dabar is a national e-infrastructure that enables higher education and research institutions in Croatia to set up interoperable institutional repositories (Dabar, 2015). As increase of number of $\mathrm{OA}$ repositories is expected, the need for educating scholars and students will also increase. 
LR

$65,4 / 5$

262

It is not so important to involve librarians in publishing OA journals, but librarians' advices could be very helpful for journals' visibility (e.g. librarians can evaluate databases, they can do citation analyses, etc.). Croatia has a respectable number of journals in OA, thanks to the national portal for scientific journals (Hrcak, 2015). In December 2015, there were 398 journals on the portal, almost all published by non-profit institutions, such as universities, faculties, associations and institutes. Libraries at those institutions can help in publishing the journals, in assuring access and quality control.

As OA is relatively new and constantly changing movement, the role of libraries in educating users about OA is very important (answer to RQ3). Education about OA could be integrated in higher education curricula, and academic librarians could be part of that education (that is the case in three institutions whose libraries are in the sample). Chen and Lin (2011) made similar conclusion - for successful IL education, librarians should be leaders, but they should also collaborate with faculty and students, embedding IL programmes in the curriculum.

Users of Croatian academic libraries are interested in acquiring OA literacy skills, and libraries recognize the interest. Some libraries manage to organize education but significant number of libraries do not, mostly because of the lack of library staff.

The results show that Croatian academic libraries are aware of the need for improving their users' OA literacy skills. They do their best but sometimes are limited with objective factors. They try to overcome those factors by their organizational skills but not always successfully. That is the reason why individual approach, although time consuming, still is the most common educational method in Croatian academic libraries (answer to RQ4). Croatian academic libraries do not have plans for user education about OA for the next two-year period (answer to RQ5). Although library spaces are very important factor in organizing user education, Croatian librarians could use digital environment more often to organize e-courses. As Beard and Dale (2010) suggest, e-resources could enhance learning experiences in digital environment, and those sources should be central to learning and literacies. Describing IL programmes in a Greek academic library, Malliari and Nitsos (2008) also conclude that there are two ways to perform literacy programmes - they could be integrated in departments' curricula and online tutorials could be created.

When comparing results from Croatian libraries at higher education institutions and those at scientific institutes, users' interests are partly different. Library users at scientific institutes are scientists. Their use of OA sources is different than students' use. Scientists use the sources as a basis for their research or they publish their own results in OA. Therefore, scientists' interests are oriented towards finding and evaluating high-quality OA sources, as well as to increase their own impact through OA. As scientists are sometimes authors, they are interested in copyright issues, and, as they produce data, they are also interested in open data. Scientists already know about the basic concept and definition of OA. Students, as users of faculty and university libraries, are less familiar with the concept of OA, so their libraries accent the importance of the topics, such as OA definitions, learning about ways to achieve OA but also evaluating OA sources (answer to $R Q 6$ ).

Results of the survey show that there is a need for organizing user education about $\mathrm{OA}$ in Croatian academic libraries. Results can also help in developing the concept of OA literacy. 


\section{Conclusion}

Numerous researchers have proven the advantages of OA model for scientific communication. Acceleration of knowledge creation, as well as wider dissemination of information, may result in better visibility and impact of research results (Bernius, 2010). The evolution of questionable publishers and journals is a huge threat to high-quality scientific communication through journals, and users of OA journals (both authors and readers) should be aware of it. Their libraries (mostly academic libraries) should develop a strategy for OA literacy education. The education could be a key solution to several problems that arise from OA - detection of questionable publishers, solving the copyright dilemma, while self-archiving, depositing material in OAI-PMH-compliant repositories, linking and using open data, etc. The research shows correlation between the concepts of $\mathrm{OA}$ and IL, connecting them and detecting basic $\mathrm{OA}$ literacy skills. Some of the skills are:

- knowing how to find and evaluate OA information;

- understanding two ways of achieving OA;

- proper self-archiving;

- understanding copyright issues and licencing;

- understanding persistent digital identifiers (e.g. author identifiers or object identifiers);

- identifying different versions of OA papers (e.g. preprint, post print, publishers' pdf);

- using advantages of new formats (such as 3D images or video material);

- detecting and avoiding questionable journals and publishers; and

- understanding alternative metrics, etc.

OA literacy should be considered as one of the aspects of IL. The new term is important to cover specific part of IL because OA publishing model is evolving and changing. The set of OA literacy skills will develop, and the need for new skills will emerge. Therefore, academic librarians should improve their own skills and organize users' education. Although some old problems are being solved (e.g. interoperability of OA repositories is solved by using OAI-PMH compliant software), new problems arise (e.g. questionable publishers are a big threat to scholarly communication today).

According to the results of the survey of Croatian academic libraries, they already educate their users but mostly through an individual approach. Some of them do more than others. In future, they should use digital environment to overcome problems of insufficient staff and library space (e.g. by organizing e-courses and e-tutorials). Further research should be done to explore those low-cost solutions - some recommendations should include development of national educational programmes but also the use of international open e-sources.

Users of Croatian academic libraries are interested in all the OA topics, and librarians should do their best to ensure that their users get appropriate OA education that would result in acquiring OA literacy competencies. To achieve that goal, libraries have to promote their new role within their institutions (ACRL, 2013). Librarians should work across traditional boundaries to prepare its users to take advantage of all the new possibilities OA offers, as well as to avoid the pitfalls. 
LR

$65,4 / 5$

264

Further researches have to be done in Croatian academic libraries (e.g. interviews with librarians to get wider image of their plans, survey of scholars to find about their attitudes and experiences with OA, survey of students to identify their level of knowledge about OA etc.).

Academic libraries were the first places to notice access crisis, and they are the right places to advocate the use of evaluated and reliable OA information. Reliability and quality can only be assured by implementing OA literacy skills. Without developing those skills among scientists and students, future of scientific communication through OA journals would be seriously endangered.

\section{References}

ALA (1989), "Presidental committee on information literacy: final report", American Library Association, Washington, 10 January, available at: www.ala.org/acrl/publications/ whitepapers/presidential (accessed 11 December 2015).

Alexandria Proclamation (2005), "Beacons of the information society: the alexandria proclamation on information literacy and lifelong learning", IFLA, UNESCO, National Forum on Information Literacy, 9, Alexandria, November, available at: www.ffla.org/publications/ beacons-of-the-information-society-the-alexandria-proclamation-on-information-literacy (accessed 11 December 2015).

Arnett, R.C., Fritz, J.M.H. and Bell, L.M. (2009), Communication Ethics Literacy: Dialogue and Differences, Sage publications, Los Angeles.

Association of College and Research Libraries (2013), "Division of the American library association", Chicago, available at: www.ala.org/acrl/sites/ala.org.acrl/files/content/ publications/booksanddigitalresources/digital/commonground_oa.pdf (accessed 19 March 2016).

Bawden, D. (2001), "Information and digital literacies: a review of concepts", Journal of Documentation, Vol. 57 No. 2, pp. 218-259.

Beard, J. and Dale, P. (2010), “Library design, learning spaces and academic literacy,” New Library World, Vol. 111 Nos 11/12, pp. 480-492. doi: 10.1108/03074801011094859.

Bernius, S. (2010), "The impact of open access on the management of scientific knowledge", Online Information Review, Vol. 34 No. 4, pp. 583-603. doi: 10.1108/14684521011072990.

BOAI (2002), "Budapest open access initiative", available at: www.budapestopenaccessinitiative. org/read (accessed 11 December 2015).

BOAI 10 (2012), "Ten years from the Budapest open access initiative: setting the default to open", available at: www.budapestopenaccessinitiative.org/boai-10-recommendations (accessed 11 December 2015).

Bot, M., Burgemeester, J. and Roes, H. (1998), "The cost of publishing in an electronic journal: a general model and a case study", D-Lib Magazine, November, available at: www.dlib.org/ dlib/november98/11roes.html (accessed 11 December 2015).

Chen, K. and Lin, P. (2011), "Information literacy in university library user education", Aslib Proceedings, Vol. 63 No. 4, pp. 399-418. doi: 10.1108/00012531111148967.

Dabar (2015), "Digitalni akademski arhivi i repozitoriji", available at: https://dabar.srce.hr/ (accessed 11 December 2015).

DOAJ (2015), "Directory of open access journals", available at: http://doaj.org/ (accessed 11 December 2015).

Duckett, K. and Warren, S. (2013), "Exploring the intersections of information literacy and scholarly communication' in", in Davis-Kahl, S. and Hensley, M.K. (Eds), Common Ground 
at the Nexus of Information Literacy and Scholarly Communication, ACRL, Chicago, pp. 25-44.

Ferguson, B. (2005), "Information literacy: a primer for teachers, librarians, and other informed people", available at: http://bibliotech.us/pdfs/InfoLit.pdf (accessed 11 December 2015).

Gelfand, J. and Palmer, C. (2013), "Weaving scholarly communication and information literacy", in Davis-Kahl, S. and Hensley, M.K. (Eds), Common Ground at the Nexus of Information Literacy and Scholarly Communication, Association of College and Research Libraries, Division of the American Library Association, Chicago, pp. 1-24, available at: www.ala.org/ acrl/sites/ala.org.acrl/files/content/publications/booksanddigitalresources/digital/ commonground_oa.pdf (accessed 19 March 2016).

Gilliver-Brown, K.E. and Johnson, E.M. (2009), "Academic literacy development: a multiple perspectives approach to blended learning", Same Places, Different Spaces, Proceedings Ascilite, Auckland, available at: www.ascilite.org.au/conferences/auckland09/procs/ gilliver-brown.pdf (accessed 11 December 2015).

Gurak, L.J. (2001), Cyberliteracy: Navigating the Internet with Awareness, Yale University Press, New Haven.

Hall, N. (2015), "The information literacy gap in scholarly communication”, available at: https:// vtechworks.lib.vt.edu/handle/10919/51824 (accessed 19 March 2016).

Harnad, S. (1994), “The subversive proposal”, in Okerson, A.S. and O’Donnell, J.J. (Eds), Scholarly Journals at the Crossroads: a Subversive Proposal for Electronic Publishing: An Internet Discussion about Scientific and Scholarly Journals and Their Future, available at: www.arl. org/storage/documents/publications/subversive-proposal-electronic-publishing-jun05.pdf (accessed 11 December 2015).

Hebrang Grgic, I. and Barbarić, A. (2011), "The future of open access in croatia: a survey of acacemic and research libraries", Library Review, Vol. 60 No. 2, pp. 155-160. doi: 10.1108/ 00242531111113096.

Hrcak (2015), "Portal of scientific journals of Croatia”, available at: http://hrcak.srce.hr/?lang=en (accessed 11 December 2015).

Ipri, T. (2010), "Introducing transliteracy: what does it mean to academic libraries?", College \& Research Libraries, Vol. 71 No. 10, pp. 532-567, available at: http://crln.acrl.org/content/71/ 10/532.full.pdf +html (accessed 11 December 2015).

Jacsó, P. (2006), “Open access to scholarly ful-text documents”, Online Information Review, Vol. 30 No. 5, pp. 587-594. doi: 10.1108/14684520610706442.

Jones-Kavalier, B.R. and Flannigan, S.L. (2006), "Connecting the digital dots: literacy of the 21st century”, Educause Quarterly, Vol. 29 No. 2, pp. 8-10, available at: http://net.educause. edu/ir/library/pdf/eqm0621.pdf (accessed 11 December 2015).

Laakso, M., Welling, P., Bukvova, H., Nyman, L., Björk, B.C. and Hadlund, T. (2011), "The development of open access journal publishing from 1993 to 2009", PLoS One, Vol. 6 No. 6 , p. e20961. doi: 10.1371/journal.pone.0020961.

Mackey, T.P. and Jacobson, T.E. (2011), "Reframing information literacy as a metaliteracy", College \& Research Libraries, Vol. 72 No. 1, pp. 62-78. doi: 10.5860/crl-76rl.

Malliari, A. and Nitsos, I. (2008), "Contribution of an information literacy programme to the education process”, Library Management, Vol. 29 Nos 8/9, pp. 700-710. doi: 10.1108/01435120810917314.

OAD (2014), "Open access directory: journal declarations of independence”, available at: http:// oad.simmons.edu/oadwiki/Journal_declarations_of_independence (accessed 11 December 2015). 
LR

$65,4 / 5$

266

Odlyzko, A. (1995), "Tragic loss or good riddance: the impending demise of traditionally scholarly journals”, International Journal of Human-Computer Studies, Vol. 42, available at: www. research.att.com/ amo (accessed 11 December 2015).

OECD (2003), "Programme for international student assessment (PISA)", available at: www.oecd. org/edu/school/programmeforinternationalstudentassessmentpisa/33690591.pdf (accessed 11 December 2015).

Ogburn, J.L. (2013), "Closing the gap between information literacy and scholarly communication", in Davis-Kahl, S. and Hensley, M.K. (Eds), Common Ground at the Nexus of Information Literacy and Scholarly Communication, Association of College and Research Libraries, Division of the American Library Association, Chicago, pp. 5-8, available at: www.ala.org/ acr1/sites/ala.org.acrl/files/content/publications/booksanddigitalresources/digital/ commonground_oa.pdf (accessed 19 March 2016).

Rizor, S.L. and Holley, R.P. (2014), "Open access goals revisited: how green and gold open access are meeting (or not) their original goals", Journal of Scholarly Publishing, Vol. 45 No. 4, pp. 321-335. doi: 10.3138/jsp.45.4.01.

SHERPA/RoMEO (2016), "Search: publishers' copyright policies \& self-archiving", available at: www.sherpa.ac.uk/romeo/search.php (accessed 19 March 2016).

Špiranec, S. and Banek Zorica, M. (2008), Informacijska Pismenost: Teorijski Okvir i Polazišta (Information Literacy: Teoretical Concept and Origin), Zavod za informacijske studije Odsjeka za informacijske znanosti Filozofskog fakulteta Sveučilišta u Zagrebu, Zagreb (in Croatian).

Špiranec, S. and Banek Zorica, M. (2012), “Information literacy 2.0: hype or discourse refinement?”, Journal of Documentation, Vol. 66 No. 1, pp. 140-153.

Suber, P. (2009), “Timeline of open access movement”, available at: http://legacy.earlham.edu/ $\sim$ peters/fos/timeline.htm (accessed 11 December 2015).

Swan, A. (2010), "The open access citation advantage: studies and results to date", available at: http://eprints.soton.ac.uk/268516/ (accessed 11 December 2015).

Wagner, B.A. (2010), "Open access citation advantage: an annotated bibliography", Issues in Science and Technology Librarianship, Vol. 60 No. 1. doi: 10.5062/F4Q81B0W.

Zurkowski, P.G. (1974), The Information Service Environment: Relationships and Priorities: Related Paper: Number Five, National Commission on Libraries and Information Science, WA, November, available at: http://files.eric.ed.gov/fulltext/ED100391.pdf (accessed 11 December 2015).

\section{Corresponding author}

Ivana Hebrang Grgic can be contacted at: ivana.grgic@ffzg.hr

For instructions on how to order reprints of this article, please visit our website:

www.emeraldgrouppublishing.com/licensing/reprints.htm

Or contact us for further details: permissions@emeraldinsight.com 